\title{
SISTEM DETEKSI KERUSAKAN SIDIK JARI DENGAN METODE LEARNING VECTOR QUANTIZATION UNTUK PENENTUAN JENIS KERUSAKANNYA
}

\author{
Yoyok Supriyono ${ }^{1}$, Uce Indahyanti $^{2}$, Sukarjadi $^{3}$ \\ Teknik Elektro \\ Politeknik SAKTI Surabaya, Indonesia
}

e-mail : ${ }^{1}$ yoyoksupri@gmail.com, ${ }^{2}$ u. indahyanti@gmail.com, ${ }^{3}$ sukaryadisakti@gmail.com

Diterima: 23 September 2018. Disetujui : 5 Desember 2018. Dipublikasikan : 10 Desember 2018

(C)2018 -TESJ Fakultas Teknik Universitas Maarif Hasyim Latif. Ini adalah artikel dengan

akses terbuka di bawah lisensi CC BY 4.0 (https://creativecommons.org/licenses/by/4.0/)

\begin{abstract}
ABSTRAK
Pengenalan terhadap sidik jari sangat dibutuhkan terutama untuk pengenalan identitas seseorang dari sifatnya yang unik. Pada saat pengambilan data sering ditemui kesalahan dan kesulitan pada pengambilan data maka perlu dilakukan identifikasi kesalahan pada sidik jari tersebut. Identifikasi, sering ditemui adanya kerusakan citra sidik jari berupa sidik jari kotor, sidik jari berminyak, sidik jari sebagian, sidi jari rotasi. Kerusakan citra sidik jari mengakibatkan citra sidik jari sulit dikenali karena ciri citra sidik jari banyak yang hilang. Untuk itu diperlukan penentuan parameter bahwa sebuah citra sidik jari dikatakan rusak kemudian mencari ekstraksi ciri yang berbeda dari jenis kerusakan citra sidik jari. Untuk menghindari kerusakan citra sidik jari, dilakukan penelitian mengenai deteksi kerusakan citra sidik jari di antaranya sidik sidik jari kotor, sidik jari berminyak, sidik jari sebagian, sidik jari rotasi. Sedangkan ekstraksi ciri menggunakan pemisah luasan defect dan non defect dan deteksi menggunakan metode Learning Vector Quantization (LVQ). Hasil yang diperoleh dari penelitian bahwasanya dengan training dan neuron yang besar kecenderungannya hasil akurasi semakin baik tersebut citra sidik jari sebagian akurasi mencapai 100\%, citra sidik jari kotor 85\%, sidi jari berminyak 96, 6\%, sidik jari rotasi $85 \%$.
\end{abstract}

Kata kunci : jenis kerusakan sidik jari, feature extraction, metode learning vector quantization (LVQ)

\section{PENDAHULUAN}

Dalam perkembangan teknologi yang sudah semakin maju, pelayanan dan keamanan kepada masyarakat juga ditingkatkan. Untuk mencegah terjadinya pemakaian identitas yang sama, digunakan teknologi biometrik.

Pada dasarnya, setiap orang memiliki identitas yang unik, hanya dimiliki oleh dirinya sendiri tanpa ada kesamaan dengan orang lain. Sistem biometrik dapat digunakan untuk identifikasi pada berbagai kondisi sosial termasuk penyelidikan kejahatan dan tindak kriminal. Sistem biometrik adalah sistem untuk melakukan identifikasi dengan menggunakan ciri-ciri fisik khusus seperti sidik jari (fingerprint), wajah, iris, retina mata dan suara. Sedangkan untuk tingkah laku yang digunakan sebagai pengenal di antaranya cara berjalan, kecepatan kedipan mata, bentuk dan cara tanda tangan. Teknologi biometrik memiliki beberapa kelebihan seperti tidak mudah hilang, tidak dapat lupa, tidak bisa dipalsukan, dan tidak mudah rusak.

Di antara seluruh indikator biometrik, sidik jari memiliki keandalan yang sangat tinggi dan sering digunakan oleh para ahli forensik di dalam investigasi kriminal untuk mengungkap kejahatan.
Efektivitas sistem deteksi kerusakan sidik jari bertujuan untuk menentukan jenis kerusakan sidik jari. Kendala utama dalam pengenalan sidik jari dengan metode berbasis minutiae, pada umumnya citra sidik jari memiliki kualitas yang rendah, disebabkan oleh jenis kulit (berminyak, kering, cacat). Oleh karena itu, perbaikan kualitas citra sidik jari seharusnya menjadi salah satu prioritas utama sebelum mengidentifikasi parameterparameter yang berupa ciri (feature) dari objek di dalam citra, untuk selanjutnya parameter tersebut digunakan dalam menginterpretasi citra untuk dapat diekstraksi ciri dari citra tersebut.

Untuk mencegah terjadinya pengulangan data dibuat sistem informasi yang dapat mengidentifikasi kerusakan sidik jari. Dapat ditentukan 5 jenis kerusakan citra sidik jari, di antaranya : sidik jari normal, sidik jari kotor, sidik jari berminyak, sidik jari sebagian dan sidik jari rotasi. sidik jari sebagai salah satu masalah kompleks yang tidak memiliki model matematis yang jelas akan dijadikan sebagai bahan masukan Jaringan Saraf tiruan (JST). Salah satu metode yang dapat melakukan proses identifikasi jenis kerusakan sidik jari dalam JST adalah metode Backpropagation. Metode ini akan memberikan umpan maju pola pelatihan input, tahap 
pemropagasi balik error dan tahap pengaturan berminyak, dan kesalahan tersebut tidak terdeteksi, kendala ini menyebabkan banyak pengulangan pengambilan data maupun pencocokan data. Kondisi ini membuang banyak waktu dan tenaga untuk mengulanginya, dengan kesalahan dari pengambilan sidik jari menjadikan data sulit dibaca, untuk itu dibut penelitian untuk deteksi kesalahan pengambilan sidik jari pada 5 kesalahan pengambilan sidik jari diantaranya : sidik jari normal, sidik jari kotor, sidik jari berminyak, sidik jari sebagian, dan sidik jari rotasi. Pengenalan ciri citra sidik jari direpresentasikan menjadi sebuah vector dan dilanjutkan dengan methode LVQ untuk mengklasifikasi vektor-vektor input memiliki nilai yang mendekati atau hampir sama untuk mengelompokkan dalam pola yang sama

\section{Sidik Jari}

Sidik jari merupakan salah satu sitem biometrik yang banyak diterapkan, hal ini dikarenakan sifat sidik jari yang uniqness dan sidik jari yang tidak pernah berubah. Berdasarkan dari pola garis pola garis (ridge) dan lembah (valley), sidik jari dapat diklasifikasikan menjadi tiga kelas utama, yaitu: Arch, Loop dan Whorl (Prabakar).

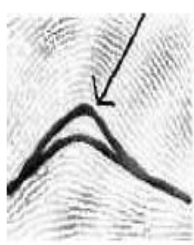

Arch

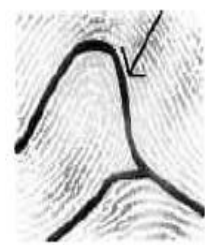

Loop

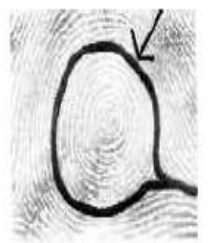

Whorl
Gambar 1. Klasifikasi pada sidik jar Arch, Loop dan Whorl (Prabakar)

Dari klasifikasi ini dapat di bagi menjadi beberapa subklasifikasi (prabakar), yaitu :

- Arch dibagi menjadi arch dan tented arch, dari beberapa populasi arch mempunyai presentasi sebesar $5 \%$

- Loop dibagi menjadi left loop, right loop dan double loop. Berbeda dengan arch, jumlah individu yang mempunyai klasifikasi loop sangat besar yaitu sebesar $60 \%$

- Whorls pada klasifikasi ini jumlah prosentasi individu sebesar 35\%

Hasil dari pengambilan citra sidik jari ditentukan dari kualitas sensor dan kondisi sidik jari yang diambil. Kondisi citra sidik jari normal (neutral) dapat diperoleh bila sensor kondisinya baik dan jenis kesalahan pengambilan sidik jari tidak ada kerusakan pada kondisi sidik jari, baik berupa kotor maupun salah letak. Adapun kerusakan yang sering terjadi adalah sidik jari kotor, sidik jari berminyak, sidik jari sebagian dan sidik jari rotasi. sidik jari kotor dapat terjadi bila terkena tinta, debu, abu dan tanah, sedang sidik jari berminyak dapat terjadi bila terkena oli, minyak rambut dan minyak goreng. Kerusakan citra sidik jari yang disebabkan letak yang tidak benar, pada sidik jari sebagian dapat terjadi bila letak sidik jari hanya sebagian saja yang dibaca sensor (core tidak kelihatan). Untuk sidik jari rotasi dapat terjadi bila letak sidik jari tidak lurus ke tengah tetapi agak miring. Hal ini akan mengakibatkan hasil yang didapat tidak sesuai dengan yang diharapkan. Adapun contoh untuk citra sidik jari yang mengalami kerusakan dapat dilihat pada Gambar 2.

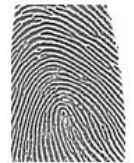

(a)

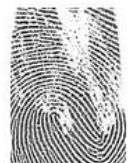

(b)

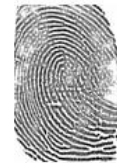

(c)

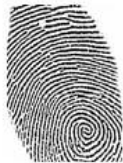

(d)

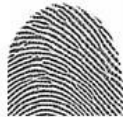

(e)
Gambar 2. Berbagai Macam Hasil Pengambilan sidik Jari:
(a) sidik Jari Normal,
(b) sidik Jari Kotor,
(c) sidik Jari Berminyak,
(d) sidik Jari Rotasi,
(e) sidik Jari Sebagian

\section{Pengolahan Citra}

Pada pengolahan citra adalah pemrosesan citra, khususnya menggunakan komputer menjadi citra yang lebih baik.

\section{Thresholding}

Konversi dari citra hitam putih ke citra biner dilakukan dengan operasi thresholding. Operasi pengambangan mengelompokkan derajat keabuan setiap pixel ke dalam 2 kelas, hitam dan putih. Dua pendekatan yang digunakan dalam operasi pengambangan adalah global image thresholding dan locally adaptive image thresholding

\section{Global Image Thresholding}

Setiap pixel didalam citra dipetakan ke dua nilai 1 atau 0 dengan fungsi pengambangan (1).

$$
f_{b}(i, j)=\left\{\begin{array}{l}
1 \\
0, f_{b}(i, j) \leq T
\end{array}\right.
$$

$f_{g}(i, j)$ adalah citra hitam putih, $f_{b}(i, j)$ adalah citra biner, dan $\mathrm{T}$ adalah nilai ambang yang dispesifikasikan. Dengan operasi pengambangan tersebut, objek dibuat berwarna gelap (1 atau hitam) sedangkan latar belakang berwarna terang ( 0 atau putih).

Nilai ambang $T$ dipilih sedemikian sehingga galat yang diperoleh sekecil mungkin. Cara yang umum menentukan nilai $T$ adalah dengan membuat histogram citra, jika citra mengandung satu buah objek dan latar belakang mempunyai nilai intensitas yang homogen, maka citra tersebut umumnya mempunyai histogram bimodal. Nilai $T$ dipilih, pada minimum lokal yang terdapat di antara 
dua puncak dengan cara ini tidak hanya konversi citra hitam putih ke biner, tetapi sekaligus melakukan segmentasi objek dari latar belakang.

\section{Locally Adaptive Image Thresholding}

Pengembangan secara global tidak selalu tepat untuk seluruh macam gambar. Beberapa informasi penting di dalam gambar mungkin hilang.

Treshold secara lokal dilakukan terhadap daerah-daerah di dalam citra. Dalam hal ini citra dipecah menjadi bagian-bagian kecil, kemudian proses pengambangan dilakukan secara lokal. Nilai ambang untuk setiap bagian belum tentu sama dengan bagian lain. Itensitas pixel yang berbeda secara signifikan dari nilai rata-rata tersebut dianggap mengandung informasi kontras dan ini harus dipertahankan di dalam citra biner. Dengan metode ini informasi yang hilang sedikit.

Thresholding digunakan untuk mengatur jumlah derajat keabuan yang ada pada citra yaitu 256 atau $2^{8}$. Dengan menggunakan thresholding maka derajat keabuan bisa diubah sesuai keinginan.

Pada threshold yang tinggi, hampir tidak tampak perbedaan karena keterbatasan mata.

\section{Konversi ke Citra Biner}

Citra biner hanya mempunyai dua nilai derajat keabuan hitam dan putih. Pixel-pixel objek bernilai 1 dan pixel-pixel latar belakang bernilai 0 . Pada waktu menampilkan gambar 0 adalah putih dan 1 adalah hitam. Pengkonversian citra hitam putih (grayscale) menjadi citra biner dilakukan untuk mengidentifikasi keberadaan objek, yang dapat dipresentasikan sebagai daerah (region) di dalam citra. Misalnya jika ingin memisahkan (segmentasi) suatu objek dari gambar latar belakangnya. Citra biner (hitam putih) merupakan citra yang banyak dimanfaatkan untuk keperluan fingerprint yang sederhana seperti pengenalan angka dan huruf. Untuk mengubah suatu citra grayscale menjadi citra biner, sebetulnya prosesnya sama dengan threshold yaitu mengubah kuantisasi citra. Untuk citra dengan derajat keabuan 256, maka nilai tengah adalah 128 sehingga untuk mengubah menjadi citra biner dapat dituliskan :

Jika $\mathrm{x}<128$ maka $\mathrm{x}=0$, jika tidak maka $\mathrm{x}=255$

\section{Segmentasi Citra Biner}

Proses awal yang dilakukan dalam menganalisi objek di dalam citra biner adalah segmentasi objek. Proses segmentasi bertujuan mengelompokkn pixel-pixel objek menjadi wilayah (region) yang merepresentasikan objek:

Adapun dua pendekatan yang digunakan dalam segmentasi objek:

1. Segmentasi berdasarkan batas wilayah (tepi dari objek).

Pixel-pixel tepi ditelusuri sehingga rangkaian pixel yang menjadi batas (boundary) antara objek dengan latar belakang dapat diketahui secara keseluruhan.

2. Segmentasi ke bentuk-bentuk dasar misalnya segmentasi huruf menjadi garis-garis vertikal dan horisontal, segmentasi objek menjadi bentuk lingkaran.

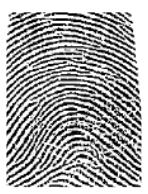

(a)

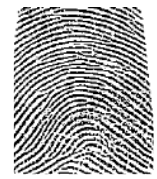

(b)
Gambar 3. Proses Konversi Binerisasi (a) citra asli, (b) hasil binerisasi

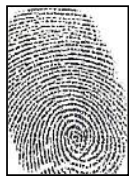

(a)

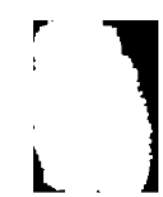

(b)
Gambar 4. Proses pemisahan (a) gambar asli (b) hasil segmentasi(Matlab).

\section{METODE PENELITIAN}

Merupakan suatu metode untuk melakukan pelatihan terhadap lapisan-lapisan kompetitif yang terawasi. Suatu lapisan kompetitif akan secara otomatis belajar untuk mengklasifikasikan vektorvektor input. Jika dua vector input memiliki nilai yang mendekati atau hamper sama maka dalam lapisan kompetitif akan mengenali kedua vektor input tersebut pada kelas yang sama. Jadi LVQ adalah metode untuk klasifikasi (pengelompokkan) pola dan memiliki output yang mewakili dari kelas tertentu.

\section{Arsitektur LVQ}

Arsitektur jaringan saraf LVQ pada dasarnya sama dengan Kohenen Self Organizing Map (tanpa suatu struktur topologis yang diasumsikan untuk output). Arsitekturnya terdiri dari lapisan input, lapisan kompetitif (lapisan tersembunyi/hidden Layer), dan lapisan output seperti pada Gambar 5. Masing-masing output memiliki kelas yang sebelumnya telah dibentuk dan dikenali dari hasil pelatihan jaringan saraf LVQ ini.

Lapisan kompetitif akan belajar secara otomatis untuk melakukan klasifikasi terhadap vektor input yang diberikan. Apabila beberapa vector input memiliki jarak yang sangat 
berdekatan, maka vector input tersebut akan dikelompokkan dalam kelas yang sama. Gambar 5 menunjukkan jaringan LVQ dengan6 unit pada lapisan input, dan 2 unit (neuron) pada lapisan output.

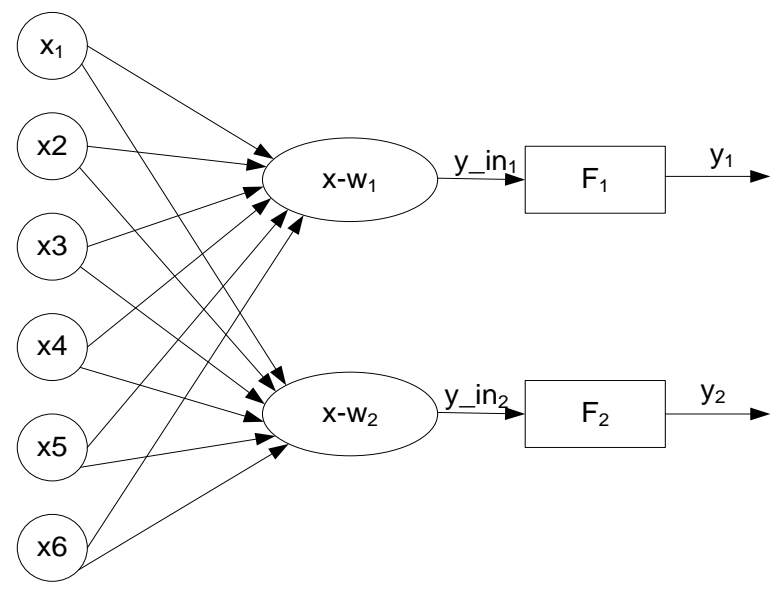

Gambar 5. Arsitektur LVQ

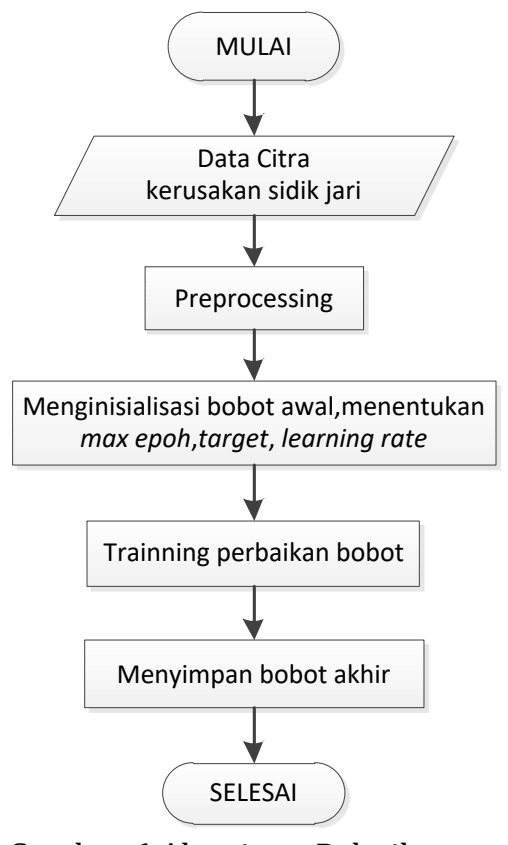

Gambar 6 Algoritma Pelatihan

Algoritma Learning Vector Quantization (LVQ)

Algoritma LVQ bertujuan akhir mencari nilai bobot yang sesuai untuk mengelompokkan vektorvektor input kedalam kelas tujuan yang telah diinisialisasi pada saat pembentukan Jaringan LVQ. Sedangkan algoritma pengujiannya adalah menghitung nilai output, yang terdekat dengan vektor input, atau dapat disamakan dengan proses pengklasifikasian (pengelompokkan). Dimana nilai vektor yang berdekatan dikelompokkan kedalam kelas yang sama sesuai dengan hasil perhitungan dengan mencari nilai kelas terdekat. (Kusumadewi, 2004)

Perbaikan bobot pada metode Learning Vector Quantization (LVQ) adalah:
Jika $T=C_{j}$ maka:

$$
W_{j}(\text { baru })=W_{j}(\text { lama })+\alpha\left[x-W_{j}(\text { lama })\right]
$$

Jika $T \neq C_{j}$ maka:

$$
W_{j}(\text { baru })=W_{j}(\operatorname{lama})-\alpha\left[x-W_{j}(\operatorname{lama})\right]
$$

\section{Desain Sistem}

Gambar7 Merupakan blok diagram sistem identifikasi kesalahan dari pengambilan sidik jari secara realtime.

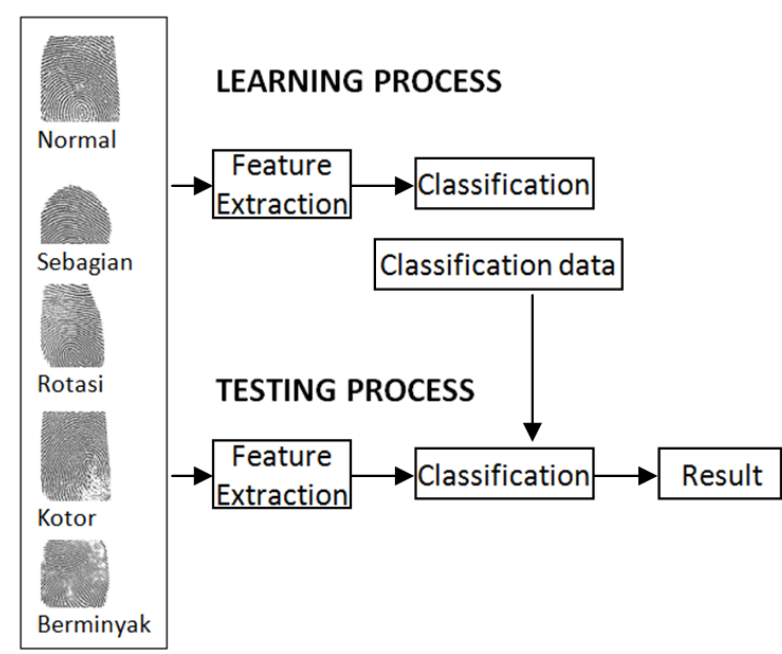

Gambar 7. Identifikasi Kesalahan Pengambilan sidik Jari

\section{Proses Identifikasi}

Proses identifikasi merupakan proses pencocokan yang dilakukan dengan mencari data dari database yang cocok dengan sidik jari yang diujikan. Dalam proses ini, hal pertama yang dilakukan adalah melakukan akuisisi terhadap sampel sidik jari. Pada penelitian ini dilakukan proses identifikasi terhadap masing-masing user dengan menggunakan variasi sidik jari sebagai berikut : sidik jari normal, sidik jari kotor, sidik jari berminyak, sidik jari sebagian dan dirotasikan. Jika program memberikan keputusan untuk menolak user tertentu, maka proses identifikasi untuk user tersebut akan memberikan keterangan jenis kesalahan.

\section{HASIL DAN PEMBAHASAN}

Dalam penelitian ini pengambilan data terhadap 70 mahasiswa dengan mengambil data sidik jari dalam 5 jenis kesalahan baik kondisi kotor maupun letak sidik jari. data diteliti untuk mendapatkan data yang akan digunakan $2 / 3$ untuk data training maupun $1 / 3$ untuk data testing. Untuk itu metode yang akan dipakai yaitu : Metode LVQ untuk mengklasifikasi data yang digunakan untuk mendeteksi jenis kesalahan data yang diambil dari sensor sidik jari berupa 5 jenis data 
sidik jari. Hasil pendeteksian dibedakan kesalahan yang terjadi yang dibandingkan dengan data template yang ada. Dari data yang berbeda dalam kondisi sidik jari terbaca sebagian, kotor, rotasi dan berminyak. Hasil dari data tersebut diekstraksi terlebih dahulu untuk mendapatkan suatu ciri yang dapat mengenali sidik jari secara cepat. Setelah mengalami proses pengenalan sidik jari kemudian hasilnya akan dicocokkan dengan semua template yang ada untuk menghasilkan kecepatan identifikasi diperlukan algoritma yang baik dengan mencari pola yang terdekat, misalkan dengan mencari ciri yang berbeda dari hasil pengambilan sidik jari.

Tabel 1. Hasil Pengenalan Citra sidik jari Normal dengan Rotasi, neuron 10, learning rate 0.01 Kelas menggunakan LVQ

\begin{tabular}{|c|c|c|}
\hline Epoch (Trainning) & Waktu (detik) & Akurasi (\%) \\
\hline 10 & 498.17 & $83.3 \%$ \\
\hline 25 & 1130 & $85 \%$ \\
\hline 50 & 2120.6 & $85 \%$ \\
\hline 75 & 3124 & $85 \%$ \\
\hline 100 & 4143.7 & $85 \%$ \\
\hline
\end{tabular}

Tabel 2. HasilPengenalan Citra sidik jari 5 klas menggunakan LVQ neuron 10, learning rate 0.01

\begin{tabular}{ccc}
\hline Epoch (Trainning) & Waktu (detik) & Akurasi (\%) \\
\hline 10 & 1097 & $72 \%$ \\
\hline 25 & 2625.5 & $82 \%$ \\
\hline 50 & 5167.1 & $86.4 \%$ \\
\hline 75 & 7726.8 & $86.5 \%$ \\
\hline 100 & 10785 & $86.6 \%$ \\
\hline
\end{tabular}

\section{PENUTUP}

Setelah dilakukan pengujian dengan menggunakan ekstraksi ciri luasan Hasil yang diperoleh menunjukkan penambahan neuron dan pelatihan yang tepat akan mendapatkan hasil yang optimal. Pada Deteksi sidik jari normal, sidik jari kotor, sidik jari rotasi, sidik jari sebagian dan berminyak mencapai rata-rata $85 \%$.

\section{DAFTAR PUSTAKA}

Challita, K., Farhat, H., \& Khaldi, K. (2010). Biometric authentication for intrusion detection systems. In 2010 First International Conference on Integrated Intelligent Computing (pp. 195-199). IEEE.

Demuth, H., \& Beale, M. (2008). Neural Network Toolbox For Use with Matlab.

Hermawan, A. (2006). Jaringan Saraf Tiruan Teori dan Aplikasi. Yogyakarta: Andi.

Kusumadewi, S. (2004). Membangun Jaringan Syaraf Tiruan Menggunakan Matlab dan Excel Link. Yogyakarta: Graha Ilmu.

Mazumdar, S., \& Dhulipala, V. (2008). Biometric Security Using Finger Print Recognition. University of California, San Diego, 3.

Prabhakar, S. (2001). Fingerprint classification and matching using a filterbank. Michigan State University. Department of Computer Science \& Engineering.

Puspitaningrum, D. (2006). Pengantar Jaringan Syaraf Tiruan. Yogyakarta: Andi Offset.

Putra, D. (2009). Sistem Biometrika. Yogyakarta: Andi Offset.

Siang, J. J. (2005). Jaringan syaraf tiruan dan pemrogramannya menggunakan Matlab. Penerbit Andi, Yogyakarta.

Vacca, J. R. (2007). Biometric technologies and verification systems. Elsevier. 
Y Supriyono, dkk / Teknika : Engineering and Sains Journal, Vol. 2, No. 2, Desember 2018, 103-108

Halaman ini sengaja dikosongkan 